Madushika, U.G.D., Ramachandra, T. and Zainudeen, N., 2021. Operational energy saving in buildings: A comparison of green vs conventional wall. In: Sandanayake, Y.G., Gunatilake, S. and Waidyasekara, K.G.A.S. (eds). Proceedings of the $9^{\text {th }}$ World Construction Symposium, 9-10 July 2021, Sri Lanka. [Online]. pp. 422-432. DOI: https://doi.org/10.31705/WCS.2021.37. Available from: https://ciobwcs.com/papers/

\title{
OPERATIONAL ENERGY SAVING IN BUILDINGS: A COMPARISON OF GREEN VS CONVENTIONAL WALL
}

\author{
U.G.D. Madushika ${ }^{1}$, T. Ramachandra ${ }^{2}$ and N. Zainudeen ${ }^{3}$
}

\begin{abstract}
The green wall concept has been introduced as one of the solutions to reduce energy demand for ventilation requirements while improving the natural vegetation in dense urban areas. Past studies revealed that the energy-saving of green walls can vary substantially, from $35 \%$ to $90 \%$ across countries such as United Kingdom (UK), Canada, Russia, Greece, China, Saudi Arabia, India, and Brazil. Given these differences in energy saving of green walls due to climatic conditions and other reasons, direct application of such findings to the Sri Lankan context is questionable. Therefore, this study aimed to assess the thermal performance of green wall applications in Sri Lanka through a case study analysis of an indirect green façade with a comparative conventional wall. The required data were extracted through on-site temperature measurements from different points of both the exterior and interior wall surfaces of each building in different time intervals per day for a period of fourteen days spanning from October to November. The analysis shows that the green walls contribute to $21 \%$ - 36\% of temperature difference compared to the conventional wall. Eventually, this results in $0.06 \mathrm{kWh}$ of energysaving per $\mathrm{m}^{2}$ of wall area, and thereby green walls contribute to the $80 \%$ energy saving for ventilation requirements. Hence, the study recommends that the use of green walls can be considered as one of the energy efficiency solutions while improving natural vegetation in tropical climatic cities and absorbing other benefits of green walls.
\end{abstract}

Keywords: Energy cost saving; Green wall; Indirect green façade; Thermal performance.

\section{INTRODUCTION}

In recent years, building designers have been searching for an effective way to enhance building energy efficiency in a sustainable manner (Pérez et al., 2014). Ottelé et al. (2011) identified that the integration of vegetation into the building is one of the retrofit technologies for energy efficiency in buildings relative to sustainable aspects. There are two main ways of integrating vegetation into the buildings: green roofs and green walls (Sheweka and Magdy, 2011). However, Dunnet and Kingsbury (2008) stated that most of the time, the green wall area could be twenty times bigger than the roof area of multi-storey buildings. Hence, it is evident that having green walls can have a more sustainable impact than the green roof in multistorey buildings. Most of the researchers illustrated that the ability to reduce heat gain and to cool the atmosphere through evapotranspiration of green walls could reduce the energy consumption for ventilation and heating meanwhile, they reduce the operational cost of building (Wong et al., 2010; Ottele et al., 2011; Pérez et al., 2011; Susorova et al., 2013; Susorova, 2015).

\footnotetext{
${ }^{1}$ Department of Building Economics, University of Moratuwa, Sri Lanka, dilakshimadushika96@gmail.com

${ }^{2}$ Department of Building Economics, University of Moratuwa, Sri Lanka, thanujar@uom.lk

${ }^{3}$ Department of Building Economics, University of Moratuwa, Sri Lanka, jabeenzain14@gmail.com
} 
Sri Lanka is gradually adapting to urban development by converting the natural vegetation into concrete buildings (Herath et al., 2018). The consequent natural vegetation depletion increases global warming (Pan and Chu, 2016). As a result of global warming, energy consumption increases to fulfil the requirement of human comfort (Sun et al., 2019). In the Sri Lankan context, more than $75 \%$ of electricity is used for ventilation and air conditioning purposes from the total energy consumption in a typical building (Geekiyanage and Ramachandra, 2018). In this context, the use of green walls can be considered as a solution to optimise the energy consumption in buildings in Sri Lanka. However, the application seems minimal, could be due to the reasons of lack of public awareness of the concept and its potential benefits, particularly about its contribution to energy saving, perception of higher initial and maintenance costs, possible aesthetic effects to the wall surface, and more time-consuming for the absorption of benefits (Jefas et al., 2012; Peiris, 2017; Rupasinghe and Halwatura, 2018).

Despite some of the global researchers such as Wong et al. (2010), Ottele et al. (2011), Pérez et al. (2011), Susorova et al. (2013), and Susorova (2015) have focused on potential energy cost-saving of green walls, the application of such research findings to the Sri Lankan context is questionable due to the geographical differences. Hence, this research aimed to assess the thermal performance of green walls through a comparison of a green wall with a comparative conventional wall of a residential facility and thereby establish the potential contribution made to savings in energy in the Sri Lankan context.

\section{LITERATURE REVIEW}

\subsection{Significance OF GREen Walls}

Green walls refer to all types of vertical vegetation surfaces such as facades, walls, blind walls, and partition walls (Newton et al., 2007; Manso and Castro-Gomes, 2015). According to Dunnet and Kingsbury (2008), vertical vegetation can be climbing or hanging upward on the vertical surface or grow downward on the vertical surface. Green walls can be divided into two main categories as the green facade and living walls according to the method of construction (Köhler, 2008; Dunnet and Kingsbury, 2008). Green facades are further classified into direct and indirect green facades; based on a climbing plant directly attached to the wall and supported with structures such as steel cables or trellis respectively (Kohler, 2008). The living wall system is more complicated than the green façade system since it has prefabricated or pre-vegetated systems on a modular panel that contains growing media with balanced nutrients (Dunnet and Kingsbury, 2008).

When considering the construction cost of these green wall types, direct green facades are more cost-effective than indirect green façade and living walls due to the absence of support structure (Manso and Castro-Gomes, 2015). However, direct green facades comprise contribute to certain disadvantages, mainly, affecting the aesthetic appearance of the wall surface with the plant roots and collapsing of plant when further grows (Dunnet and Kingsbury, 2008). Manso and Castro-Gomes (2015) stated that indirect green facades and living walls are a solution to overcome those disadvantages of direct green facades. However, the construction cost of living walls is comparatively higher than indirect green facades.

The green wall concept has spread over the residential, office, commercial, and government buildings around the world with its numerous benefits (McCullough et al., 2018). In addition to the energy cost saving in green walls, it enhances the biodiversity in high-density urban areas with supporting foods and habitats for the animals (Lundholm, 2006), mitigates the urban heat island effect (Busato et al., 2014), and improve the air quality (Ottelé et al., 2010). Furthermore, Vox et al. (2018) stated that the green wall concept is mainly related to improving real estate 
value or rental value. Moreover, Ottele et al. (2011) identified that the green wall concept contributes to less external wall surface maintenance by absorbing the Ultra-Violet (UV) rays fallen onto the wall. However, the amount of benefits gained through the green walls depends on the green wall type, application, and the foliage thickness of the plant (Perez et al., 2011; Perini and Rosasco, 2013; Huang et al., 2019). Therefore, the study gives due consideration to those parameters in selecting the building for its energy assessment due to green walls.

\subsection{ENERgy COST SAVING IN GREEN WALLS}

The importance of green wall applications has become the forefront with the ability to reduce heat transfer between internal and external environments through plants (Susorova, 2015; Libessart and Kenai, 2018). Figure 1 shows the physical thermal process of the energy balance of the vegetated surface.

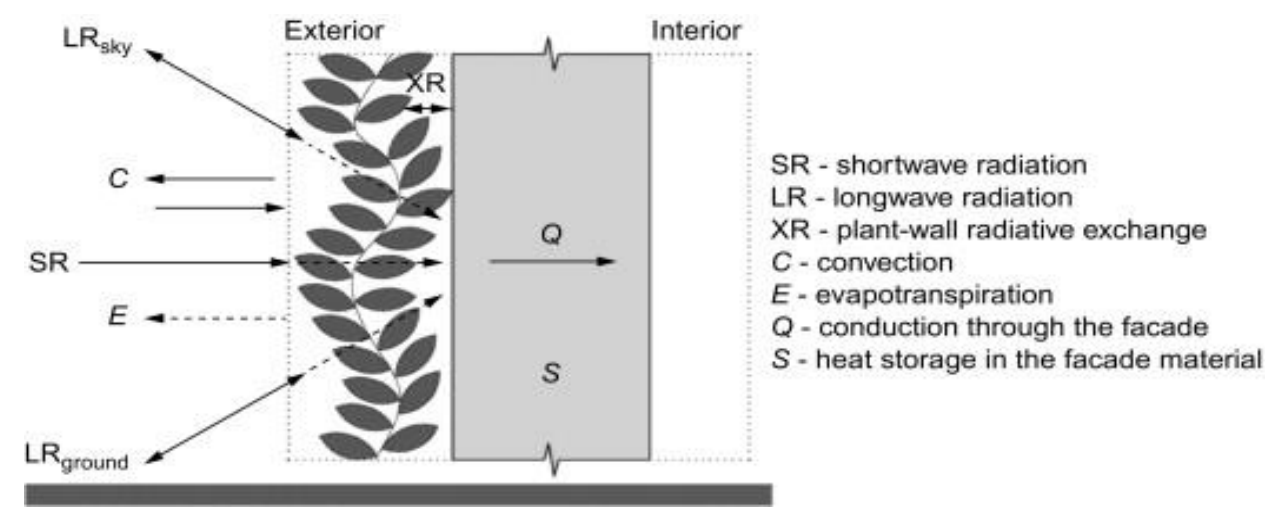

Figure 1: Energy balance of a vegetated façade (Source: Gates, 2003)

According to Larcher (2003) and Straube (2005), the thermal process of the energy balance of the vegetated surface can be listed as follows. Shortwave solar radiation is received by the building wall through the sun. Longwave radiation also exchanges between ground, sky, and surrounding surfaces. Then those radiations are absorbed by the walls and transferred back into the environment by convection or transferred to the building interior by conduction. Some amount of energy is stored in the wall material. The authors further derived the following equations for energy balance:

The energy balance of a conventional/bare wall (bw) is;

$$
S R_{b w}+L R_{b w}+C_{b w}=Q_{b w}+S_{b w}
$$

The energy balance of a vegetated wall (vw) is;

$$
S R_{v w} L R_{v w} X R_{+} C_{v w}=Q_{v w}+S_{v w}
$$

The foregoing review evidences that the plant layer acts as an additional thermal insulation layer.

Gates (2003) stated that the study of energy balance and heat flows through a vegetated wall surface of a building is important to evaluate the thermal performance and potential energy saving of green walls.

Table 1 illustrates the findings of some studies that depict the heat flows through green walls. 
Table 1: Heat flows through green walls

\begin{tabular}{|c|c|c|c|c|c|c|}
\hline \multirow{2}{*}{$\begin{array}{c}\text { Type of } \\
\text { Green } \\
\text { Wall }\end{array}$} & \multirow[t]{2}{*}{ Plant Species } & \multirow{2}{*}{$\begin{array}{c}\text { Foliage } \\
\text { thickness } \\
\quad(\mathrm{cm})\end{array}$} & \multirow{2}{*}{$\begin{array}{c}\text { Climate } \\
\text { (Koppen } \\
\text { classification) }\end{array}$} & \multicolumn{2}{|c|}{$\begin{array}{c}\text { Temperature } \\
\text { reduction }\left({ }^{0} \mathrm{C}\right)\end{array}$} & \multirow[t]{2}{*}{ Source } \\
\hline & & & & $\begin{array}{c}\text { External } \\
\text { wall }\end{array}$ & $\begin{array}{c}\text { Internal } \\
\text { wall }\end{array}$ & \\
\hline Direct & $\begin{array}{l}\text { Parthenociss } \\
\text { us } \\
\text { tricuspidata }\end{array}$ & 25 & $\mathrm{Cfb}$ & 5.7 & 0.9 & $\begin{array}{l}\text { (Eumorfopoulou } \\
\text { and Kontoleon, } \\
2009 \text { ) }\end{array}$ \\
\hline Indirect & $\begin{array}{l}\text { Climber } \\
\text { plants }\end{array}$ & - & Af & 4.36 & - & $\begin{array}{l}\text { (Wong et al., } \\
\text { 2010) }\end{array}$ \\
\hline Direct & $\begin{array}{l}\text { Hereda helix } \\
\text { Hereda helix, } \\
\text { Vitis, }\end{array}$ & 20 & & 1.2 & - & \\
\hline Indirect & $\begin{array}{l}\text { Clematis, } \\
\text { Jasminum, } \\
\text { Pyracantha }\end{array}$ & 10 & $\mathrm{Cfb}$ & 2.7 & - & $\begin{array}{l}\text { (Perini et al., } \\
\text { 2011) }\end{array}$ \\
\hline $\begin{array}{l}\text { Living } \\
\text { wall }\end{array}$ & $\begin{array}{l}\text { Evergreen } \\
\text { species }\end{array}$ & 10 & & 5 & - & \\
\hline Indirect & $\begin{array}{l}\text { Wisteria } \\
\text { sinensis }\end{array}$ & 20 & Csa & 15.8 & - & $\begin{array}{l}\text { (Pérez et al., } \\
\text { 2011) }\end{array}$ \\
\hline Direct & Hereda helix & $10-45$ & $\mathrm{Cfb}$ & $1.7-9.5$ & - & $\begin{array}{l}\text { (Sternberg et } \\
\text { al., 2011) }\end{array}$ \\
\hline Direct & $\begin{array}{l}\text { Parthenociss } \\
\text { us } \\
\text { tricuspidata }\end{array}$ & - & Dfa & 7.9 & 2 & $\begin{array}{l}\text { (Susorova et al., } \\
\text { 2013) }\end{array}$ \\
\hline $\begin{array}{l}\text { Living } \\
\text { wall }\end{array}$ & $\begin{array}{l}\text { Climber } \\
\text { plants }\end{array}$ & - & $\mathrm{Cfb}$ & 20.8 & - & $\begin{array}{l}\text { (Chen et al., } \\
\text { 2013) }\end{array}$ \\
\hline
\end{tabular}

From the review of Table 1, it is evident that the heat flow through the green walls depends on various factors such as climate, green wall type, and vegetation type.

Furthermore, most researchers identified that the green walls significantly contribute to the energy saving of buildings through their ability to less heat flow through a building's external and internal wall surfaces.

Bass and Baskaran (2001) found that the implementation of green walls helps to reduce energy cooling load by $23 \%$, energy for fans by $20 \%$, and as a result that, annual energy consumption by $8 \%$. Furthermore, Alexandri and Jones (2008) concluded that, if all possible facades covered with vegetations, energy saving can vary from $90 \%$ to $35 \%$ by conducting computational fluids dynamics simulation to main cities in the United Kingdom (UK), Canada, Russia, Greece, China, Saudi Arabia, India, and Brazil. These countries have different climatic conditions. Hence, the potential energy saving of green walls also depends on the climate.

Additionally, Wong et al. (2009) researched the variation of cooling load based on the foliage thickness of the green wall and showed that the 74\% cooling load reduction in a building with a fully covered wall with the vegetation, $10 \%$ cooling load reduction in a wall with $50 \%$ covered with vegetation and rest 50\% glazing and 32\% cooling load reduction in fully covered vegetation on the fully glazed wall. Price (2010) developed a mathematical model to evaluate energy efficiency in low-rise buildings with an indirect green façade and found that building cooling load reduced by $28 \%$ in a temperate climate. Pan and Chu (2016) researched the energy savings of green walls in Hong Kong and demonstrated that green walls contribute to $16 \%$ 
saving of the energy consumed for air conditioning in the months of August and September which are typical summer months.

\section{RESEARCH METHODOLOGY}

The study primarily used a quantitative approach where the required data were collected from preliminary survey and a comparative analysis. Initially, a preliminary survey was carried out into various sources such as site visits, internet, green wall suppliers, and green rating systems (GREEN $^{\text {SL }}$ Rating System and LEED Certification) to identify green wall applications in Sri Lanka. Accordingly, forty-three (43) applications were identified through green wall suppliers (18), green rating systems (12), site visits (11), and internet surveys (6). The summary of identified cases is illustrated in Table 2 and further discussed in the following sections.

Table 2: Green wall application

\begin{tabular}{lcccccccc}
\hline \multicolumn{1}{c}{ Building } & No & \multicolumn{3}{c}{ Green Wall Type } & \multicolumn{3}{c}{ Application } \\
\cline { 2 - 8 } & & Direct & Indirect & $\begin{array}{c}\text { Living } \\
\text { wall }\end{array}$ & $\begin{array}{c}\text { External } \\
\text { wall }\end{array}$ & $\begin{array}{c}\text { Internal } \\
\text { wall }\end{array}$ & $\begin{array}{c}\text { Boundary } \\
\text { wall }\end{array}$ \\
\hline Hotel & 15 & 8 & 5 & 2 & 4 & 1 & 10 \\
Residential & 10 & 2 & 6 & 2 & 6 & 2 & 2 \\
Industrial & 8 & - & 6 & 2 & 6 & 1 & 1 \\
Office & 7 & - & 7 & - & 6 & - & 1 \\
Educational & 2 & 1 & 1 & - & 2 & - & - \\
Religious & 1 & - & 1 & - & 1 & - & - \\
\hline Total & 43 & 11 & 26 & 6 & 25 & 4 & 14 \\
\hline
\end{tabular}

Among the 43 green wall cases, indirect green façade is the most used in Sri Lanka, compared to direct green facades and living walls. According to Perini and Rosasco (2013) and Huang et al. (2019), the application of green walls to the exterior walls of a building greatly contributes to the energy-saving of a building. Accordingly, it is evidenced that applications to external walls are significant in the Sri Lankan context. Furthermore, the amounts of energy savings gained from the green walls depend on the amount of the foliage thickness (Pérez et al., 2011). Hence, it was decided to select a building profile that contains an indirect green wall on the exterior wall surface of the building with significant foliage thickness to evaluate the thermal performance of the green wall effectively. From the 43 cases, only nine (9) cases were comprised of the green walls covering the entire building envelope. The remaining cases were limited to the boundary walls and internal walls (partition walls) of the buildings with less green wall coverage. Of the nine (09) buildings, due to the COVID 19 pandemic situation and related data accessibility and time constraints, it was possible to choose one case study of green walls. Furthermore, for this comparative study, there needs to be two buildings: with green walls and without green walls with similar physical properties which would influence the thermal performance and energy. Hence, when selecting the cases, due consideration was given to location, purpose, building shape, and size and thereby to ensure the reliability and accuracy of the research findings.

Based on aforementioned factors, a temple building (Religious) in Matara $\left(5.95^{\circ} \mathrm{N}, 80.54^{\circ} \mathrm{E}\right.$, classified as tropical rainforest climate [Af], according to the Koppen climate classification), was selected as it contained buildings with both green walls and conventional walls in the same location. 
Heat transfer through the conventional wall and green wall was calculated to evaluate the thermal performance of the indirect green façade. The ground floor walls of the green wall building were not covered with the climbing plant. Hence, the first and second floors of each building were selected to obtain the field measurements. An infrared thermometer and relative humidity meter were used to obtain the on-site temperature and relative humidity measurements. Measurements were taken for fourteen days scattered over the period from $21^{\text {st }}$ October to $14^{\text {th }}$ November in each building due to the time restrictions. The rays of the sun that fall on the external wall surface are not constant at every point. It changes due to the orientation of the building (North, South, West, East), the composition of the external wall, and surrounding buildings. Hence, to increase the accuracy of this study, temperature measurements were taken from different points on the first and second floors of each building. All measurements were taken from both the outer surface and inner surface of the walls. The intensity of solar radiation is not constant throughout the day. Therefore, to increase the reliability of the study, measurements were taken at five-time intervals per day (8.30a.m., 10.30a.m., 12.30p.m., 3.00p.m. and 5.00p.m.). Ultimately, the mean values of obtained measurements were considered to calculate the energy saving cost.

\subsection{Profile OF THE SELECTED BuILdings}

Both buildings selected for the study are rectangular in shape. Even though these buildings belong to the temple, they are used for residential purposes. The longitudinal sides of both buildings are oriented to the North and South directions. All sides of the building are fully exposed to the sunlight without obstructing from surrounding objects. An indirect green façade is present in one of these buildings. The plant is well grown around the wall surface of the building except for the south wall and the ground floor. Thunbergia laurifolia is the climbing plant used in this building. Average foliage thicknesses of north, east, and west wall surfaces are $45 \mathrm{~cm}, 15 \mathrm{~cm}$, and $12 \mathrm{~cm}$, respectively. The support structure is made of one and a half-inch dia Galvanized Iron (GI) pipes and 3mm Polyethylene terephthalate (PET) wire. Table 3 illustrates the summary of both building profiles.

Table 3: Summary of building profiles

\begin{tabular}{lll}
\hline \multicolumn{1}{c}{ Description } & \multicolumn{1}{c}{$\begin{array}{c}\text { Indirect Green Façade } \\
\text { Building }\end{array}$} & \multicolumn{1}{c}{$\begin{array}{c}\text { Conventional Wall } \\
\text { Building }\end{array}$} \\
\hline Number of floors & 3 floors with a rooftop & 3 floors with a rooftop \\
Floor height & $3.3 \mathrm{~m}$ & $3.3 \mathrm{~m}$ \\
Exterior dimensions & Length $-22.6 \mathrm{~m}$ & Length $-14.7 \mathrm{~m}$ \\
& Width $-9.75 \mathrm{~m}$ & Width $-8.10 \mathrm{~m}$ \\
GIFA per floor & $210.74 \mathrm{~m}^{2}$ & $125.28 \mathrm{~m}^{2}$ \\
Service life & 3 years & 4 years \\
A/C & - & - \\
Wall type & Block Wall & Block Wall \\
Wall thickness & $150 \mathrm{~mm}$ & $150 \mathrm{~mm}$ \\
Wall Finishing (Internal & Plastering + Painting & Plastering + Painting \\
and External) & & \\
Window type & Louver Aluminum framed & Louver Aluminum framed \\
& glazed windows & glazed windows \\
Door type & Louver Aluminum Door & Louver Aluminum Door \\
\hline
\end{tabular}




\section{DATA COLLECTION AND ANALYSIS}

\subsection{Thermal Performance of Green Wall}

Based on the geometric mean temperature of each day, the average temperature difference between the external and internal surfaces of both conventional wall and green wall was calculated separately and the summary is presented in Table 4 . The outer surface and inner surface are represented as $\mathrm{O}$ and I respectively.

Table 4: Summary of average temperature

\begin{tabular}{|c|c|c|c|c|c|c|c|c|c|c|c|c|}
\hline \multicolumn{13}{|c|}{ Indirect Green Façade Building - Average Surface Temperature $\left({ }^{0} \mathrm{C}\right)$} \\
\hline \multirow[t]{2}{*}{ Location } & \multicolumn{2}{|c|}{ North Wall } & \multicolumn{4}{|c|}{ East Wall } & \multicolumn{2}{|c|}{ West Wall } & \multicolumn{4}{|c|}{ South Wall } \\
\hline & $\mathbf{O}$ & $\mathbf{I}$ & O- I & $\mathbf{O}$ & $\mathbf{I}$ & O- I & $\mathbf{O}$ & I & O- I & $\mathbf{O}$ & $\mathbf{I}$ & O- I \\
\hline $1^{\text {st }}$ Floor & 28.9 & 28.7 & 0.18 & 29.1 & 28.9 & 0.21 & 30.0 & 29.6 & 0.42 & 30.6 & 30.0 & 0.65 \\
\hline $2^{\text {nd }}$ Floor & 28.9 & 28.8 & 0.16 & 29.1 & 28.9 & 0.22 & 29.7 & 29.4 & 0.28 & 30.6 & 29.9 & 0.70 \\
\hline \multicolumn{13}{|c|}{ Conventional Wall Building - Average Surface Temperature $\left({ }^{\circ} \mathrm{C}\right)$} \\
\hline $1^{\text {st }}$ Floor & 30.1 & 29.3 & 0.77 & 30.6 & 29.4 & 1.18 & 30.8 & 29.8 & 0.98 & 30.5 & 29.6 & 0.87 \\
\hline $2^{\text {nd }}$ Floor & 30.2 & 29.2 & 0.91 & 30.7 & 29.4 & 1.30 & 30.8 & 29.9 & 0.93 & 30.5 & 29.7 & 0.82 \\
\hline
\end{tabular}

According to Table 4, in all points of location, a significantly higher temperature difference increment is observed in the conventional wall compared to the green wall. This temperature difference indicates the heat loss through the wall surface. Furthermore, the temperature behaviour of north, east, and west walls are approximately equal in indirect green façade buildings. However, temperature measurements of the south wall, which are not covered with the indirect green façade are considerably high and similar to the conventional wall building.

The following formula was used to calculate the heat transfer through the external wall surface of both building profiles.

$$
Q=\frac{K \cdot A \cdot \Delta \theta}{L}
$$

Where, $\mathrm{Q}=$ Heat Transfer $(\mathrm{W}), \Delta \Theta=$ Temperature Difference $\left({ }^{0} \mathrm{C}\right), \mathrm{L}=$ Thickness of Surface $(\mathrm{m}), K=$ Thermal Conductivity $\left(\mathrm{W} / \mathrm{m}^{0} \mathrm{C}\right), A=$ Heat Transfer Area $\left(\mathrm{m}^{2}\right)$

According to The Engineering Toolbox (2020), the thermal conductivity of the blocks was considered as $1.7 \mathrm{~W} / \mathrm{m}^{0} \mathrm{C}$. Furthermore, $1 \mathrm{~m}^{2}$ of wall surface was considered in heat calculation.

Heat transfer calculations for wall surfaces of both buildings are shown in Table 5 .

Table 5: Heat transfer calculations for green wall and conventional wall

\begin{tabular}{lll}
\hline & \multicolumn{1}{c}{ Indirect Green Façade per $\mathbf{~ m}^{2}$} \\
\hline \multirow{2}{*}{ North wall } & $Q=\frac{1.7 \times 1 \times 0.18}{0.15}=2.04$ & Second Floor $(\mathrm{W})$ \\
East Wall & $Q=\frac{1.7 \times 1 \times 0.21}{0.15}=2.41$ & $Q=\frac{1.7 \times 1 \times 0.16}{0.15}=1.79$ \\
West Wall & $Q=\frac{1.7 \times 1 \times 0.42}{0.15}=4.76$ & $Q=\frac{1.7 \times 1 \times 0.22}{0.15}=2.50$ \\
South Wall & $Q=\frac{1.7 \times 1 \times 0.65}{0.15}=7.34$ & $Q=\frac{1.7 \times 1 \times 0.28}{0.15}=3.17$ \\
& & \\
\hline
\end{tabular}




\begin{tabular}{lll}
\hline & \multicolumn{2}{c}{ Conventional Wall per $\mathbf{~ m}^{2}$} \\
\hline Forth wall & $Q=\frac{1.7 \times 1 \times 0.77}{0.15}=8.68$ & Second Floor $(\mathrm{W})$ \\
East Wall & $Q=\frac{1.7 \times 1 \times 1.18}{0.15}=13.36$ & $Q=\frac{1.7 \times 1 \times 0.91}{0.15}=10.35$ \\
West Wall & $Q=\frac{1.7 \times 1 \times 0.98}{0.15}=11.16$ & $Q=\frac{1.7 \times 1 \times 1.30}{0.15}=14.73$ \\
South Wall & $Q=\frac{1.7 \times 1 \times 0.87}{0.15}=9.89$ & $Q=\frac{1.7 \times 1 \times 0.93}{0.15}=10.57$ \\
& &
\end{tabular}

According to the above calculations, conventional wall accounts for $88.06 \mathrm{~W}$ heat transfer per $\mathrm{m}^{2}$ of wall area. However, the wall surfaces of the building which is having an indirect green façade account for $31.93 \mathrm{~W}$ per $\mathrm{m}^{2}$. Generally, the building requires equivalent energy as the cooling energy for this transferred heat through the wall surface. As per Table 5, the conventional wall is responsible for an additional heat transfer of $56.13 \mathrm{~W}$ per $\mathrm{m}^{2}$. Hence, the energy required for the cooling purposes of a building with an indirect green façade is relatively lower than the conventional wall building.

Table 6 presents the heat transfer and energy requirement through the selected conventional and green walls.

Table 6: Summary of heat transfer and energy requirement of conventional wall and green wall

\begin{tabular}{lcc}
\hline & Green Façade Building & Conventional Wall Building \\
\hline Heat transfer $\left(\mathrm{W} / \mathrm{m}^{2}\right)$ per day & 31.93 & 88.06 \\
Energy requirement per month $(\mathrm{kWh})$ & 204.52 & 397.53 \\
\hline
\end{tabular}

Green walls contribute to a reduction in heat transfer through the exterior and interior wall surfaces and the energy requirement of a building compared to the building with the conventional wall as evidenced in Table 6.

Using current unit rates published by the Ceylon Electricity Board (CEB) of Sri Lanka - 2020 for domestic buildings, monthly and annual energy costs for both buildings were calculated and presented in Table 7.

Table 7: Annual energy consumption of both buildings

\begin{tabular}{|c|c|c|c|}
\hline \multirow[t]{2}{*}{ Description } & \multirow{2}{*}{$\begin{array}{c}\text { Unit rate } \\
(\mathbf{L K R} / \mathbf{k W h})\end{array}$} & \multicolumn{2}{|c|}{ Amount (LKR) } \\
\hline & & $\begin{array}{c}\text { Indirect Green Façade } \\
\text { Building } \\
\text { (Energy consumption per } \\
\text { month }=\mathbf{2 0 4 . 5 2} \mathrm{kWh} \text { ) }\end{array}$ & $\begin{array}{c}\text { Conventional Wall } \\
\text { Building } \\
\text { (Energy consumption per } \\
\text { month }=\mathbf{3 9 7 . 5 3 ~ k W h )}\end{array}$ \\
\hline For first $60 \mathrm{~kW}$ & 7.85 & 471.00 & 471.00 \\
\hline For Next 30kW & 10.00 & 300.00 & 300.00 \\
\hline For Next 30kW & 27.75 & 832.50 & 832.50 \\
\hline For Next $60 \mathrm{~kW}$ & 32.00 & $1,920.00$ & $1,920.00$ \\
\hline For rest & 45.00 & $1,103.40$ & $9,788.85$ \\
\hline Fixed & & 540.00 & 540.00 \\
\hline \multicolumn{2}{|c|}{ Total (Per Month) - Building } & $5,166.90$ & $13,852.25$ \\
\hline \multicolumn{2}{|c|}{ Total (Per Month) - Per m² } & 24.20 & 92.05 \\
\hline
\end{tabular}




\begin{tabular}{lccc}
\hline Description & Unit rate & \multicolumn{2}{c}{ Amount (LKR) } \\
\cline { 2 - 3 }$(\mathbf{L K R} / \mathbf{k W h})$ & $\begin{array}{c}\text { Indirect Green Façade } \\
\text { Building }\end{array}$ & $\begin{array}{c}\text { Conventional Wall } \\
\text { Building }\end{array}$ \\
& $\begin{array}{c}\text { (Energy consumption per } \\
\text { month } \mathbf{2 0 4 . 5 2} \mathbf{~ k W h )}\end{array}$ & $\begin{array}{c}\text { (Energy consumption per } \\
\text { month }=\mathbf{3 9 7 . 5 3} \mathbf{~ k W h})\end{array}$ \\
& $62,002.80$ & $166,228.20$ \\
Total (Per Annum) - Building & 290.39 & 1140.65 \\
Total (Per Annum) - Per m ${ }^{2}$ & & \\
\hline
\end{tabular}

According to Table 7, the energy cost per $\mathrm{m}^{2}$ of a wall area in a green wall building is Rs. 290.39 per annum while the same for the conventional wall is Rs. 1140.65 per annum. Hence, the green wall building shows Rs. 850.26 cost-saving per $\mathrm{m}^{2}$ than the conventional wall per annum. In other words, indirect green façade building shows $80 \%$ of energy cost-saving than the conventional wall building.

\section{DISCUSSIONS}

Green walls contribute to saving the energy requirement for cooling and ventilation purposes of buildings via maintaining the building's internal temperature (Susorova, 2015; Libessart and Kenai, 2018). It is due to the less heat transfer through the external wall surface with the presence of green walls. The data retrieved through the case study analysis of the current study also supports the above statement.

Moreover, Sternberg et al. (2011) stated that, during the daytime, the exterior façade surface temperature is reduced by a $1-9^{0} \mathrm{C}$ due to vegetation on the wall surface than the wall without vegetation layer. Similarly, as per Table 5, the exterior surface temperature of the green wall is always lesser than the conventional wall's external surface temperature. However, there was no such high difference in temperature reduction between the green wall and conventional wall observed in this study. The difference was limited to $0.8^{0} \mathrm{C}-1.5^{\circ} \mathrm{C}$. The reason for this dissimilarity could be due to the use of green wall type and the climate difference between the two studies. Sternberg et al. (2011) conducted a study regarding the direct green façade on $\mathrm{Cfb}$ climate (Reference to Koppen Climate Classification) and this study focused on indirect green façade on Af climate. However, Wong et al. (2010) conducted a study on indirect green façade on Af climatic condition and showed that the temperature reduction of $4.36^{\circ} \mathrm{C}$ of external wall surface, which is having a vegetation layer. Hence, it is evidenced that the thermal performance of green walls not only depends on the green wall type and the climate. There seem other reasons such as façade orientation, foliage thickness, and vegetation type which could contribute to the different degrees of temperature difference.

In agreement with that, Pérez et al. (2011) depicted that the thermal performance of green walls varies with the foliage thickness and the orientation of the façade. As per Table 4, a lower average surface temperature difference of $0.16^{\circ} \mathrm{C}$ is shown by the north wall with $45 \mathrm{~cm}$ of average foliage thickness. West wall has a less average foliage thickness compared to other sides and shows a high surface temperature difference of $0.42^{\circ} \mathrm{C}$. This proved that the plant layer in the exterior wall surface of green walls provides an additional insulation layer and helps to reduce heat conduction through the exterior façade. Therefore, the literature findings were proved further by the case study analysis.

Furthermore, the analysis results indicate that the indirect green façade building accounts for $80 \%$ of energy cost-saving than the conventional wall building. This supports the finding in previous studies Alexandri and Jones (2008). Alexandri and Jones (2008) concluded that, if all possible facades are covered with vegetation, energy saving can vary from $90 \%$ to $35 \%$. Moreover, Pan and Chu (2016) stated that green walls contribute to saving $16 \%$ of the energy 
consumed for air conditioning in hot and wet summer seasons in Hong Kong. However, this figure has been derived by considering the seasonal changes are in Hong Kong while no such seasonal changes are visible in Sri Lanka. Hence, the energy-saving percentage is considerably less than the findings of the current study. This further shows that the potential energy saving of green walls depends on the climatic conditions.

\section{CONCLUSIONS}

In this study, a comparative analysis of the thermal performance of green walls and conventional walls was performed to determine the energy-saving contribution of green walls. From the study findings, it was apparent that all common building types: commercial, residential, and office have incorporated with the most popular indirect green façade type in Sri Lanka. Direct green facades are mostly applied to the boundary walls in the hotel buildings with the intention of aesthetic appearance. Energy cost saving for cooling and ventilation purposes of buildings via maintaining the building's internal temperature is a significant benefit of green walls. The current study found that the significant temperature difference increment in the conventional wall compared to the indirect green façade and thereby indirect green façade building accounts for $80 \%$ of energy cost-saving than the conventional wall building. Hence, it is expected that the findings of the study would convince the public of the awareness and perceptions about the energy-saving cost benefits of green walls and thereby enhance its application in the Sri Lankan context.

This study has limited its focus only to energy aspect of the most used type of green wall, indirect green façade type in Sri Lanka. However, there are other types of less commonly used green walls and green walls offer benefits beyond energy saving. Therefore, it is recommended that these aspects need to be evaluated comprehensively for effective implementation of green walls and to absorb its optimum potential.

\section{REFERENCES}

Alexandri, E. and Jones, P., 2008. Temperature decreases in an urban canyon due to green walls and green roofs in diverse climates. Building and Environment, 43(4), pp. 480-493.

Bass, B. and Baskaran, B., 2001 . Evaluating rooftop and vertical gardens as an adaptation strategy for urban areas, Report No. NRCC-46737.

Busato, F., Lazzarin, R.M. and Noro, M., 2014. Three years of study of the urban heat island in Padua: experimental results. Sustainable Cities and Society, 10, pp. 251-258.

Chen, Q., Li, B. and Liu, X., 2013. An experimental evaluation of the living wall system in hot and humid climate. Energy and Buildings, 61, pp. 298-307.

Dunnet, N. and Kingsbury, N., 2008. Planting green roofs and living walls. Oregon: Timber Press.

Eumorfopoulou, E.A., and Kontoleon, K.J., 2009. Experimental approach to the contribution of plant-covered walls to the thermal behavior of building envelopes. Building and Environment, 44(5), p. 1024-1038.

Gates, D.M., 2003. Biophysical ecology. New York: Springer-Verlag.

Geekiyanage, D. and Ramachandra, T., 2018. A model for estimating cooling energy demand at early design stage of condominiums in Sri Lanka. Journal of Building Engineering, 17, pp. 43-51.

Herath, H.M.P.I.K., Halwatura, R.U. and Jayasinghe, G.Y., 2018. Evaluation of green infrastructure effects on tropical Sri Lankan urban context as an urban heat island adaptation strategy. Urban Forestry \& Urban Greening., 29, pp. 212-222.

Huang, Z., Lu, Y., Wong, N.H. and Poh, C.H., 2019. The true cost of "greening" a building: life cycle cost analysis of Vertical Greenery Systems (VGS) in tropical climate. Journal of Cleaner Production, 228, pp. 437-454.

Jefas, M., Chandratilake, R. and Silva, N.D., 2012. Implement the vertical greenery wall (facade) to multi-stored buildings in the Sri Lankan context. ICSBE-2012: International Conference on Sustainable Built Environment, pp. 2-13.

Köhler, M., 2008. Green facades - A view back and some visions. Urban Ecosystems, 11(4), pp. 423-436. 
Larcher, W., 2003. Physiological plant ecology. $4^{\text {th }}$ ed. Berlin: Springer.

Libessart, L. and Kenai, M.A., 2018. Measuring thermal conductivity of green-walls components in controlled conditions. Journal of Building Engineering, 19, pp. 258-265.

Lundholm, J.T., 2006. Green roofs and facades: A habitat template approach. Urban Habitats., 4(1), pp. 87-101.

Manso, M. and Castro-Gomes, J., 2015. Green wall systems: A review of their characteristics. Renewable and Sustainable Energy Reviews, 41, pp. 863-871.

McCullough, M.B., Martin, M.D. and Sajady, M.A., 2018. Implementing green walls in schools. Frontiers in Psychology, 9, pp. 1-5.

Newton, J., Gedge, D., Early, P. and Wilson, S., 2007. Building greener: Guidance on the use of green roofs, green walls, and complimentary features on buildings. London: CIRIA.

Ottelé, M., Bohemen, V.H.D. and Fraaij, A.L.A., 2010. Quantifying the deposition of particulate matter on climber vegetation on living walls. Ecological Engineering, 36(2), pp. 154-162.

Ottelé, M. et al., 2011. Comparative life cycle analysis for green facades and living wall systems. Energy and Buildings, 43, pp. 3419-3429.

Pan, L. and Chu, L.M., 2016. Energy saving potential and life cycle environmental impacts of a vertical greenery system in Hong Kong: A case study. Building and Environment, 96, pp. 293-300.

Peiris, M.D.W., 2017. Exploring Enablers and Barriers of Vertical Greenery in Sri Lanka, Sri Lanka: University of Moratuwa.

Perez, G., Coma, J., Martorell, I. and Cabeza, L.F., 2014. Vertical Greenery Systems (VGS) for energy saving in buildings: A review. Renewable and Sustainable Energy Reviews, 39, pp. 139-165.

Perez, G. et al., 2011. Green vertical systems for buildings as passive systems for energy savings. Applied Energy, 88(12), pp. 4854-4859.

Perini, K. et al., 2011. Vertical greening systems and the effect on air flow and temperature on the building envelope. Building and Environment, 46(11), pp. 2287-2294.

Perini, K. and Rosasco, P., 2013. Cost-benefit analysis for green façades and living wall systems. Building and Environment, pp. 110-121.

Price, J, W., 2010. Green facade energetics. Thesis (Master). University of Maryland.

Rupasinghe, H. and Halwatura, R., 2018. Vertical greening: A sustainable approach for greener cities. FIDIC ASIA-PACIFIC conference, pp. 7-12.

Sheweka, S. and Magdy, N., 2011. The living walls as an approach for a healthy urban environment. Energy Procedia, 6, p. 592-599.

Sternberg, T., Viles, H., and Cathersides, A., 2011. Evaluating the role of ivy (Hedera Helix) in moderating wall surface microclimates and contributing to the bio protection of historic buildings. Building and Environment, 46(2), pp. 293-297.

Straube, J.A., 2005. Building science for building enclosures. Building Science Press.

Sun, Q. et al., 2019. Global heat stress on health, wildfires, and agricultural crops under different levels of climate warming. Environment International, 128, pp. 125-136.

Susorova, I., 2015. Green facades and living walls: Vertical vegetation as a construction material to reduce building cooling loads. In Eco-efficient Materials for Mitigating Building Cooling Needs, pp. 127-153.

Susorova, I., Angulo, M., Bahrami, P. and Stephens, B., 2013. A model of vegetated exterior facades for evaluation of wall thermal performance. Building and Environment, 67, pp. 1-13.

The Engineering Toolbox, 2020. Thermal conductivity of selected materials and gases. [Online] Available from: https://www.engineeringtoolbox.com/thermal-conductivity-d_429.html

Vox, G., Blanco, I. and Schettini, E., 2018. Green façades to control wall surface temperature in buildings. Building and Environment, 129, pp. 154-166.

Wong, N.H. et al., 2010. Thermal evaluation of vertical greenery systems for building walls. Building and Environment, 45(3), pp. 663-672.

Wong, N.H., Tan, A.Y.K., Tan, P.Y. and Wong, N.C., 2009. Energy simulation of vertical greenery systems. Energy and Buildings, 41(12), pp. 1401-1408. 